\title{
Quantitative and qualitative loss of tomato fruits during mechanized harvest
}

\author{
Túlio de A. Machado ${ }^{1}$, Haroldo C. Fernandes ${ }^{2}$, Clarice A. Megguer ${ }^{1}$, Nerilson T. Santos 3 \& Fabio L. Santos ${ }^{4}$ \\ ${ }^{1}$ Instituto Federal Goiano/Campus Morrinhos/Unidade Acadêmica de Agronomia. Morrinhos, GO. E-mail: machado.tulio@gmail.com (Corresponding \\ author) - ORCID: 0000-0002-6298-1938; megguer.clarice@gmail.com - ORCID: 0000-0001-9203-183X \\ ${ }^{2}$ Universidade Federal de Viçosa/Departamento de Engenharia Agrícola. Viçosa, MG. E-mail: haroldo@ufv.br - ORCID: 0000-0001-5276-5441 \\ ${ }^{3}$ Universidade Federal de Viçosa/Departamento de Estatística. Viçosa, MG. E-mail: nerilson.terra@gmail.com - ORCID: 0000-0003-0334-6640 \\ ${ }^{4}$ Universidade Federal de Lavras/Departamento de Engenharia. Lavras, MG. E-mail: ffabiolss@gmail.com - ORCID: 0000-0003-1197-7338
}

\section{Key words:}

mechanical damage

postharvest

Solanum lycopersicum L.

\begin{abstract}
A B S T R A C T
The use of mechanization in the harvesting of industrial tomatoes provides greater yield and speed of this stage. However, mechanical intervention in this process may alter the physiology of harvested fruits. Therefore, the objective of this study was to measure the quantitative losses of tomato fruits and to verify the physico-chemical behavior of fruits harvested based on physicochemical analysis in harvesters with different hours of use. Three self-propelled harvesters of the same brand and model with different working hours were used. Manually selected or undamaged fruits were harvested; afterwards, mechanized harvesting was carried out. Firmness, titratable acidity, soluble solids content $\left({ }^{\circ} \mathrm{Brix}\right), \mathrm{pH}$, weight loss and fruit status classification proposed by the Ministry of Livestock, Agriculture and Food Supply of 2002 were evaluated. Quantitative losses were divided into: losses on vines, losses on soil and total losses. It was found that the number of hours worked by the harvester did not affect the quantitative losses. The amount of overall damage in a certain amount of fruit is greater when the harvester has a greater number of hours worked. Mechanized harvesting affected the physical attributes of the fruits, such as firmness and percentage of weight loss.
\end{abstract}

\section{Palavras-chave:}

injúria mecânica

pós-colheita

Solanum lycopersicum L.

\section{Perdas quantitativas e qualitativas dos frutos de tomate durante a colheita mecanizada}

\section{R E S U M O}

O uso da mecanização na colheita do tomate industrial proporciona maior rendimento e rapidez desta etapa. Entretanto, a intervenção mecânica nesse processo pode alterar a fisiologia dos frutos colhidos. Portanto, objetivou-se com o trabalho mensurar em colhedoras, com diferentes horas de uso, as perdas quantitativas de frutos de tomate e verificar o comportamento físico-químico dos frutos colhidos a partir de análises físico-químicas. Foram utilizadas três colhedoras autopropelidas da mesma marca e modelo com diferentes números de horas de trabalho. Colheu-se os frutos manualmente selecionados ou sem danos; posteriormente, realizou-se a colheita mecanizada. Foram avaliados a firmeza, acidez titulável, teor de sólidos solúveis ( $\left.{ }^{\circ} \mathrm{Brix}\right), \mathrm{pH}$, perda de massa e a classificação quanto ao estado dos frutos proposta pelo Ministério da Agricultura Pecuária e Abastecimento de 2002. As perdas quantitativas foram divididas entre: perdas nas ramas, perdas no solo e perdas totais. Foi constatado que o número de horas trabalhadas pela colhedora não influiu nas perdas quantitativas. A quantidade de danos gerais em uma determinada quantidade de frutos é maior quando a colhedora possui um maior número de horas trabalhadas. A colheita mecanizada afetou os atributos físicos dos frutos, tais como a firmeza e a porcentagem de perda de massa. 


\section{INTRODUCTION}

Currently, Brazil occupies the $5^{\text {th }}$ position in the world in tomato production for industrial processing and, among the Brazilian states with highest production for this variety, Goiás stands out with a cultivated area of 12,670 ha and a mean yield of 75,000 kg ha-1 (Camargo et al., 2016).

Mechanized harvest of industrial tomato in Brazil has shown greater technical/economic reliability due to the better cost-benefit ratio, making it attractive for most producers who practice it (Machado et al., 2014).

In the current harvesters, the models of the shaking system are based on the use of rotary mechanisms which have low rotations in operation, reduced size, with low requirement of energy to separate fruits, and less noise (Arazuri et al., 2010).

The quality of fruits for the intended purposes depends on their physical, chemical, technological and sensory characteristics (specific to each cultivar). These characteristics are related to dimensions, mass, volume, density, shape, color of epidermis and pulp (Nachtigal \& Migliorini, 2011).

In addition to the factors which cause impact during harvest, the changes in fruit composition during maturation have been studied through some quality characteristics such as: fruit size, acidity, soluble solids, contents of sugars, texture, among others (Ferreira et al., 2010).

In this context, this study aimed to measure quantitative losses and evaluates physico-chemical attributes of tomato fruits subjected to mechanized harvest performed by mechanical harvesters with different ages in relation to hours of work.

\section{Material AND Methods}

The experiment was conducted at the Santa Rosa Farm, located in the municipality of Morrinhos, Goiás, Brazil. The mean altitude of the property is $770 \mathrm{~m}$, at longitude and latitude of $17^{\circ} 44^{\prime} 31.7^{\prime \prime} \mathrm{S}$ and $49^{\circ} 03^{\prime} 12.6^{\prime \prime} \mathrm{W}$, respectively. The experimental area was limited to a 58 ha under a central pivot. The relief is considered as gently undulating (10\%) in the area, which had been previously cultivated with sweet corn. At harvest, the soil had mean water content of $20 \%$ and soil moisture was analyzed using the methodology proposed by EMBRAPA (2011). The prevailing soil is Dark Red Latosol (EMBRAPA, 2013).

The experiment used the hybrid tomato cultivar HEINZ 9553, grown and conducted in a direct seeding system. Harvest was carried out at 125 days after transplanting and, for the evaluations of losses and physical-chemical damages in the fruits, the samplings were performed in three self-propelled harvesters manufactured by GUARESI, model G-89/93 MS 40", with 175-hp FIAT-Iveco engine, suspended harvesting platform and equipped with an electronic sorter of green fruits and clods. The harvesters with different hours of operation were: (M1) $8762 \mathrm{~h}$, (M2) $5787 \mathrm{~h}$ and (M3) $5222 \mathrm{~h}$.

The maintenance of all machines evaluated was done before harvesting started. During the harvest period, the harvesters worked regularly in the harvested areas until data collection. The harvested area was similar in terms of slope, moisture content and texture of the soil for all machines, since they were in the same site.

During the tests with the harvesters, the mean velocity of operation was $1.14 \mathrm{~m} \mathrm{~s}^{-1}$ and all used the same configuration of gear and the same engine rotation of $1900 \mathrm{rpm}$. Operational velocity was assessed during the time in which each harvester traveled $50 \mathrm{~m}$ at stable regime of operation.

All harvesters were operated with the same configuration for the cutting-harvesting platform and the shaking system. In the rotating shaker, the configuration suggested by the manufacturer was adopted (present in the manual of operation), which consisted of a $12 \mathrm{rpm}$ rotation and $2.5 \mathrm{~Hz}$ vibration. The sensor to separate clods and green fruits was turned off during the operation because most fruits were at the maturity stage desired by the industry. Thus, fruits and impurities were selected only by the workers who were on the conveyor belt of each harvester.

For physico-chemical evaluation, ten fruits were randomly collected by hand within the experimental area before the mechanical harvester passed. All of these fruits were at harvest point, with uniform and red color. The fruits in these samples were considered as undamaged and were used as control treatment, because they were not mechanically affected by the harvesters.

For evaluation after mechanized harvest, fruits were collected at the outlet of the discharge belt, bagged, identified and taken to the laboratory for physico-chemical analysis. The same analysis were carried out for manually and mechanically harvested fruits.

The following attributes were evaluated: firmness, titratable acidity, soluble solids ( ${ }^{\circ} \mathrm{Brix}$ ), $\mathrm{pH}$, weight loss and fruit status classification according to the ordinance No. 85 of March 6, 2002 (Brasil, 2002). Firmness was determined by the applanation method (Calbo \& Nery, 1995), by analyzing five fruits per replicate with two measurements per fruit. Titratable acidity was determined by the official methodology, described by AOAC (2010). Soluble solids ( ${ }^{\circ}$ Brix) were determined using a portable refractometer from Instrutemp with $0-32{ }^{\circ}$ Brix scale. Measurements of $\mathrm{pH}$ were taken using a benchtop Lucadema pH meter, model Luca 210P. For weight loss determination, the fruits were weighed at $0,24,48,72,96$ and $120 \mathrm{~h}$ after harvest. The loss was estimated in relation to the initial weight of the fruits before treatment and after the last weighing, and its values were transformed to percentage of weight loss.

To analyse the values of each classification with respect to fruit status proposed by the ordinance of MAPA, seven samples were collected in each harvester. These boxes contained samples composed of fruits which moved from the discharge belt to the truck. After classification with respect to fruit status, the weight of each quantity of fruits classified was transformed to percentage in relation to the total weight contained in each box.

A randomized block design was used, in which the mean values of each classification were subjected to analysis of variance and Tukey test at 0.05 probability level.

Manually and mechanically harvested samples were composed of seven replicates, with seven fruits in each sample contained in each treatment. A randomized block design was adopted, in which the values of the analysis of physico-chemical 
attributes of manually harvested fruits in each harvester tested were subjected to analysis of variance and Tukey test at 0.05 probability level.

Then, with the collected values, Pearson's correlation at 0.05 significance level was carried out to evaluate the existence of significant correlation between the evaluated characteristics.

Quantitative losses of the harvesters were evaluated by determining the number of non-harvested fruits and those that did not detach from the vines. Losses were quantified using a $2.5 \mathrm{~m}^{2}$ template; after the harvester passed, fruits on the soil and on the vines which were within the delimited area were collected at each one of the sampling points (Cunha et al., 2014). Seven replicates were used for each type of loss and for each harvester evaluated.

After fruit collection, the values were extrapolated to tha ${ }^{-1}$ and then subjected to analysis of variance, and means were compared by Tukey test at 0.05 probability level. All statistical analyses were carried out using the software program Minitab $17.0^{\circ}$.

\section{Results AND Discussion}

Table 1 presents the percentage of fruits considered as good, cracked, bored, with overall defects and green, and the classification of the load according to the 2002 classification of MAPA.

The means of the samples collected from each harvester were classified as "Special", because this category, according to the norm, has more than $50 \%$ of fruits identified as good. All machines reached such level, regardless of their hours of operation. In relation to good fruits, the machine (M3), with lowest number of worked hours, obtained lower quantity of overall damages on the fruits compared to the others.

After verifying the classification of the fruits from the mechanized harvest, the results for the influence of machine age in the mechanized harvest on the postharvest quality of tomatoes for industrial processing, compared to the manual harvest, were presented in Table 2.

Firmness and weight loss were affected by the harvest system: firmness decreased by around $37.57 \%$ and weight loss increased by $216.80 \%$. Fruits manually collected and those harvested by the three machines showed no statistical differences with respect to titratable acidity and $\mathrm{pH}$, which allows to state that mechanized harvest did not influence these chemical attributes.
Compared with the control, the firmness was lower in mechanically harvested fruits than in those considered as without damages. There was no significant difference between tomatoes harvested by the three machines, which led to results that allow to infer that there was direct influence of the windrowing steps (pre-harvest) and of the internal mechanisms of the harvester. Texture loss probably occurred because of the impacts of the fruits on the rigid surfaces during these processes.

Taheri-Garavand et al. (2011), evaluating the correlation between tomato weight and different physical attributes through linear and nonlinear models in three different classifications, concluded that in transport and harvest the fruits are exposed to mechanical loads which can cause lesions by cutting and/or crushing, causing qualitative and quantitative losses.

The means for soluble solids contents were lowest in fruits harvested by (M1) and did not differ statistically from (M3). The lower values of soluble solids ( ${ }^{\circ}$ Brix) in fruits harvested by (M3) are due to the higher percentage of cracked fruits, with values close to those observed in fruits harvested by (M1).

Like mechanical damages (overall defects), the damages caused by pests (bored fruits) cause an increase in respiration. It is known that the respiration process leads to great degradation of reserve substance, such as sugars, and consequently to a reduction in the contents of soluble solids (D'Aquino, et al. 2016).

Regarding the weight loss in tomatoes, Rab et al. (2013) concluded that the change in fresh matter may have been caused by the loss of water through fruit transpiration and by resistance to moisture loss, which can decrease as the fruit progresses in maturation.

Mendes et al. (2011) evaluated vegetable products and concluded that, within few minutes after a physical damage, there was an increase in respiration, ethylene production and other biochemical reactions responsible for changes in color, texture and nutritional quality. For Beckles (2012), the maturity stage of tomato at harvest, as well as the pre- and post-harvest control, are essential factors to guarantee fruit quality.

Among the attributes evaluated, the only significant correlations occurred between firmness and weight loss, and between titratable acidity and soluble solids (Table 3 ).

Table 1. Classification of tomato (\%) with respect to the damages characterized by the ordinance No. 85 of March 6, 2002

\begin{tabular}{ccccccc}
\hline Machine (M) & Good & Cracked & Bored & Overall defects & Green & Classification \\
M1 & $61.74 \mathrm{~b}$ & $12.17 \mathrm{a}$ & $0.76 \mathrm{a}$ & $24.52 \mathrm{a}$ & $0.81 \mathrm{~b}$ & Special \\
M2 & $58.78 \mathrm{~b}$ & $10.90 \mathrm{a}$ & $1.67 \mathrm{a}$ & $22.10 \mathrm{a}$ & $6.55 \mathrm{a}$ & Special \\
M3 & $68.46 \mathrm{a}$ & $12.26 \mathrm{a}$ & $2.08 \mathrm{a}$ & $17.10 \mathrm{~b}$ & $0.10 \mathrm{~b}$ & Special \\
\hline
\end{tabular}

Means followed by at least one lowercase letter in the column do not differ statistically by Tukey test at 0.05 probability

Table 2. Means and the respective standard deviations for: Firmness $\left(\mathrm{N} \mathrm{cm}^{-2}\right)$, titratable acidity (\% of citric acid), soluble solids ( ${ }^{\circ}$ Brix), $\mathrm{pH}$ and weight loss (\%) for the control and for the machines

\begin{tabular}{cccccr}
\hline & Firmness & Titratable acidity & Soluble solids & pH & Weight loss \\
C & $3.54 \pm 0.51 \mathrm{a}$ & $0.50 \pm 0.05 \mathrm{a}$ & $4.42 \pm 0.32 \mathrm{a}$ & $4.54 \pm 0.05 \mathrm{a}$ & $3.57 \pm 1.49 \mathrm{~b}$ \\
(M1) & $2.23 \pm 0.28 \mathrm{~b}$ & $0.51 \pm 0.04 \mathrm{a}$ & $4.01 \pm 0.41 \mathrm{~b}$ & $4.87 \pm 0.71 \mathrm{a}$ & $11.66 \pm 3.53 \mathrm{a}$ \\
(M2) & $2.27 \pm 0.25 \mathrm{~b}$ & $0.55 \pm 0.04 \mathrm{a}$ & $4.48 \pm 0.16 \mathrm{a}$ & $4.40 \pm 0.10 \mathrm{a}$ & $9.53 \pm 1.07 \mathrm{a}$ \\
(M3) & $2.14 \pm 0.49 \mathrm{~b}$ & $0.48 \pm 0.05 \mathrm{a}$ & $4.15 \pm 0.18 \mathrm{ab}$ & $4.57 \pm 0.07 \mathrm{a}$ & $12.75 \pm 3.04 \mathrm{a}$ \\
\hline
\end{tabular}

C - Control, M1, M2 and M3 - Machine 1, Machine 2 and Machine 3; Means followed by at least one lowercase letter in the column do not differ statistically by Tukey test at 0.05 probability 
Table 3. Pearson's correlation between the physiological attributes measured in mechanically harvested fruits

\begin{tabular}{|c|c|c|c|c|}
\hline & $\begin{array}{c}\text { Titratable } \\
\text { acidity }\end{array}$ & $\begin{array}{l}\text { Soluble } \\
\text { solids }\end{array}$ & $\mathrm{pH}$ & $\begin{array}{l}\text { Weight } \\
\text { loss }\end{array}$ \\
\hline Firmness & $-0.222^{\text {ns }}$ & $-0.200^{\text {ns }}$ & $0.194^{\mathrm{ns}}$ & $0.793^{*}$ \\
\hline Titratable acidity & ---- & $0.776^{*}$ & $0.312^{\text {ns }}$ & $-0.506^{n s}$ \\
\hline Soluble solids & --- & --- & $-0.069^{\text {ns }}$ & $-0.471^{\mathrm{ns}}$ \\
\hline pH & ---- & ---- & ---- & $0.393^{\text {ns }}$ \\
\hline Weight loss & --- & --- & --- & ---- \\
\hline
\end{tabular}

The relation between fruit firmness and weight loss became evident in the data presented in Table (2), in which the highest variations were equivalent. This behavior is evidenced by the damages on the fruits, which directly contribute to the physicochemical alterations through metabolic changes in the fruits, such as the respiration rate.

Tomatoes are highly susceptible to fast water loss, which is determined by the weight loss; this occurs due to the thin epidermis, which has low resistance to mass transfer (García et al., 2014). Weight losses of up to $10 \%$ were found in cherry tomato, after 25 days of storage at $5{ }^{\circ} \mathrm{C}$ and 80 to $85 \% \mathrm{RH}$ (Fagundes et al., 2015) and, corroborating the present study, it can be noted that weight loss values of about $10 \%$ are tolerated in the marketing of fresh fruits.

However, since these tomatoes are intended for the industry, it is believed that this loss is not relevant for visual quality, but it indicates that the mechanical damages were decisive in the greater weight loss of the products. Regarding fruits which remained at greater depths, it can be concluded that they were subjected to higher levels of compression.

According to Ferreira et al. (2004), high values of the relation between titratable acidity and soluble solids lead to mild taste because of the excellent combination between sugar and acid, whereas low values are correlated with acid and unpleasant or astringent taste, for being more adequate for processing, corroborating the result found in the present study.

Table 4 presents the results for quantitative losses of the harvesters with different hours of use with respect to losses on vines, on soil and total losses. For losses on vines, (M1), (M2) and (M3) had mean losses of 2.55, 2.19 and $9.84 \mathrm{t} \mathrm{ha}^{-1}$, respectively.

The data relative to machine (M3) differed statistically from the others and obtained highest losses, despite having the lowest number of worked hours. Total loss in M3 was directly influenced by the high value of losses on vines (branches) and $75 \%$ of this loss consisted of inefficiency of the shaking system. For the losses on soil, M2 obtained the best performance among the machines evaluated.

In this context, the machines may have been subject to interferences by the wear of the cutting-harvesting mechanisms

Table 4. Means ( $\mathrm{t} \mathrm{ha}^{-1}$ ) and respective standard deviations for the losses on vines (branches), on soil and total losses in the harvest with three different machines (M1), (M2) and (M3)

\begin{tabular}{lllr}
\hline & Loss on vines & Loss on soil & Total loss \\
(M1) & $2.55 \pm 1.48 \mathrm{~b}$ & $3.70 \pm 0.98 \mathrm{a}$ & $6.25 \pm 1.97 \mathrm{~b}$ \\
(M2) & $2.19 \pm 0.57 \mathrm{~b}$ & $2.17 \pm 0.37 \mathrm{~b}$ & $4.36 \pm 0.81 \mathrm{~b}$ \\
(M3) & $9.84 \pm 3.62 \mathrm{a}$ & $3.27 \pm 0.73 \mathrm{a}$ & $13.11 \pm 3.89 \mathrm{a}$ \\
\hline
\end{tabular}

Means followed by at least one lowercase letter in the column do not differ statistically by Tukey test at 0.05 probability and shaking system, because all machines were already at the final period of the season. Besides the factors already mentioned, the different operators may have influenced the losses on soil, because they regulate the height of the cutting platform.

Losses may have different origins, both before and during harvest. However, in this context, Cunha \& Zandergen (2007) state that 80 to $85 \%$ of losses in mechanized harvest occur due to the action of the mechanisms of the cutting platform of the harvesters, $12 \%$ caused by internal mechanisms (shaking, separation and cleaning) and $3 \%$ caused by natural dehiscence.

Also regarding the origin of the losses Pelóia et al. (2010) claim that variations in losses are related to the six factors machine, raw material, environment, method, measurement and labor established by the quality programs, and which should be investigated and eliminated from the production process.

\section{Conclusions}

1. The harvester with lowest number of worked hours obtained highest amount of fruits classified as good within a load.

2. The number of worked hours by the harvester directly influenced quantitative losses.

3. The amount of overall damages in a certain number of fruits is greater when the harvester has a lower number of worked hours.

4. Mechanized harvest affected physical characteristics of the fruits, such as firmness and weight loss, and for mechanically harvested fruits there was correlation between firmness and weight loss percentage and between titratable acidity and soluble solids.

\section{Literature Cited}

AOAC - Association of Official Analytical Chemists. Official methods of analysis. 18.ed. Washington: AOAC, 2010. 1094p.

Arazuri, S.; Arana, I.; Jaren, C. Evaluation of mechanical tomato harvesting using wireless sensors. Sensors, v.10, p.11126-11143, 2010. https://doi.org/10.3390/s101211126

Beckles, D. M. Factors affecting the postharvest soluble solids and sugar content of tomato (Solanum lycopersicum L.) fruit. Postharvest Biology and Technology, v.63, p.129-140, 2012. https://doi.org/10.1016/j.postharvbio.2011.05.016

Brasil. Ministério da Agricultura, Pecuária e Abastecimento. Portaria SARC No. 85 de 06 de março de 2002. Propõe o regulamento técnico de identidade e qualidade para classificação do tomate. Brasília: Diário Oficial da República Federativa do Brasil, 2002.

Calbo, A. G.; Nery, A. A. Medida de firmeza em hortaliças pela técnica de aplanação. Horticultura Brasileira, v.13, p.14-18, 1995.

Camargo, M. S.; Brito Júnior, J. S.; Molena, L. A. Alta nos custos limita rentabilidade em 2016. Hortifruti Brasil, v.15, p.14-17, 2016.

Cunha, J. P. A. R. da; Zandergen, H. P. Perdas na colheita mecanizada da soja na região do Triângulo Mineiro e Alto Paranaíba, Brasil. Bioscience Journal, v.23, p.61-66, 2007.

Cunha, J. P. B.; Machado, T. A.; Santos, F. L.; Coelho, L. M. Perdas na colheita de tomate industrial em função da regulagem da colhedora. Pesquisa Agropecuária Tropical, v.44, p.363-369, 2014. https://doi.org/10.1590/S1983-40632014000400006 
D’Aquino, S.; Mistriotis, A.; Briassoulis, D.; Lorenzo, M. L. di; Malinconico, M.; Palma, A. Influence of modified atmosphere packaging on postharvest quality of cherry tomatoes held at 20 ${ }^{\circ} \mathrm{C}$. Postharvest Biology and Technology, v.115, p.103-112, 2016. https://doi.org/10.1016/j.postharvbio.2015.12.014

EMBRAPA - Empresa Brasileira de Pesquisa Agropecuária. Manual de métodos de análise de solo. 2.ed. Rio de Janeiro: Embrapa Solos, 2011.230p.

EMBRAPA - Empresa Brasileira de Pesquisa Agropecuária. Sistema brasileiro de classificação de solos. 3.ed. Brasília: Embrapa Informação Tecnológica, 2013. 353p.

Fagundes, C.; Moraes, K.; Pérez-Gago, M. B.; Palou, L.; Maraschin, M.; Monteiro, A. R. Effect of active modified atmosphere and cold storage on the postharvest quality of cherry tomatoes. Postharvest Biology and Technology, v.109, p.73-81, 2015. https:// doi.org/10.1016/j.postharvbio.2015.05.017

Ferreira, S. M. R.; Freitas, R. J. S. de; Lazzari, E. N. Padrão de identidade e qualidade do tomate (Lycopersicon esculentum Mill.) de mesa. Ciência Rural, v.34, p.329-335, 2004. https://doi. org/10.1590/S0103-84782004000100054

Ferreira, S. M. R.; Quadros, D. A. de; Karkle, E. N. L.; Lima, J. J. de; Tullio, L. T.; Freitas, R. J. S. de. Qualidade pós-colheita do tomate de mesa convencional e orgânico. Ciência e Tecnologia de Alimentos, v.30, p.858-864, 2010.
García, M.; Casariego, A.; Díaz, R.; Roblejo, L. Effect of edible chitosan/zeolite coating on tomatoes quality during refrigerated storage. Emirates Journal of Food and Agriculture, v.26, p.238-246, 2014. https://doi.org/10.9755/ejfa.v26i3.16620

Machado, T. A.; Coelho, L. M.; Cunha, J. P. B.; Santos, F. L. Configuração acertada. Cultivar Máquinas, v.136, p.33-35, 2014.

Mendes, T. D. C.; Santos, J. S. dos; Vieira, L. M.; Cardoso, D. S. C. P.; Finger, F. L. Influência do dano físico na fisiologia pós-colheita de folhas de taioba. Bragantia, v.70, p.682-687, 2011. https://doi. org/10.1590/S0006-87052011000300026

Nachtigal, J. C.; Migliorini, L. C. Recomendações para o cultivo da goiabeira no Rio Grande do Sul. 1.ed. Pelotas: Embrapa Clima Temperado, 2011. 8p.

Pelóia, P. R.; Milan, M.; Romanelli, T. L. Capacity of the mechanical harvesting process of sugar cane billets. Scientia Agricola, v.67, p.619623, 2010. https://doi.org/10.1590/S0103-90162010000600001

Rab, A.; Rehman, H.; Haq, I.; Sajid, M.; Nawab, K.; Ali, K. Harvest stages and pre-cooling influence the quality and storage life of tomato fruit. Journal of Animal and Plant Sciences, v.23, p.13471352, 2013.

Taheri-Garavand, A.; Rafiee, S.; Keyhani, A. Study on some morphological and physical characteristics of tomato used in mass models to characterize best post harvesting options. Australian Journal of Crop Science, v.5, p.433-438, 2011. 